\title{
Improving the Global Energy Industry by Integrating Macro-Technologies: Challenges and Opportunities for Corporations
}

\author{
Jose M. “Chema” Martínez-Val Piera \\ ETSI Minas, Universidad Politécnica de Madrid, Madrid, Spain \\ Email: chemaval@gmail.com
}

Received October 8, 2013; revised November 8, 2013; accepted November 15, 2013

Copyright (C) 2013 Jose M. "Chema” Martínez-Val Piera. This is an open access article distributed under the Creative Commons Attribution License, which permits unrestricted use, distribution, and reproduction in any medium, provided the original work is properly cited. In accordance of the Creative Commons Attribution License all Copyrights (C) 2013 are reserved for SCIRP and the owner of the intellectual property Jose M. "Chema” Martínez-Val Piera. All Copyright (C) 2013 are guarded by law and by SCIRP as a guardian.

\begin{abstract}
Emerging energy technologies and market evolution of some energy products, particularly natural gas, can converge to produce a new global scenario closer to the objectives of Sustainable Development, with a smooth transition that would avoid social and economic upheavals and could open a new cycle of growth and wealth. The first steps of unconventional gas production have induced stabilization in the gas spot price that should be continued to guarantee stable prices in the long term. Another line of development that should start a second phase of consolidation and cost reduction is the field of Renewable Energies. Besides research and technology advancements, a new financial deal could substitute for subsidies and feed-in tariffs. Last but not least, electric vehicles and other emerging technologies from the demand side will also have a main role in this quest to re-structure the Energy sector, where a new hierarchy of energy goods and energy applications will appear, and a better integral use of energy will take place. A main consequence of that will be a significant reduction of $\mathrm{CO}_{2}$ emissions, and a cheaper cost of energy, although fiscal policies could swallow this advantage. In this transition, which would likely last thirty years or so, energy corporations will have to face challenges and opportunities to consolidate their working and value-adding status.
\end{abstract}

Keywords: $\mathrm{CO}_{2}$ Emissions; Cost of Energy; Electric Vehicle; Gas, Renewable Energies; Sustainable Development

\section{Introduction, Background and Foreground}

A few decades ago, an actual revolution started in computation and information management, which was the base for coining the term "Knowledge Society" to identify a new paradigm that would make it possible to manage all the relevant facts at once, although with scattered and fragmented information on a subject, and to take decisions with full knowledge. Wisdom was therefore guaranteed by assembling data and facts, but something did not work as expected, and the "Knowledge Society" was unable to predict and avoid the international economic crisis. No higher success has been obtained in pulling countries out from that crisis.

In spite of these new tools for assembling all relevant information for a given goal, the experience shows that information is not enough to take decisions, and goal identification seems mainly dependent on political and technical criteria which are not always fully explicit. This is why classical reports and books as those devoted to Sustainable Development [1-3] are still true references for addressing the re-structure of the Energy sector.

Tacit knowledge [4] is a concept that can complement this analysis. It is usually decisive at corporation level to establish strategies, and it goes unnoticed for the information gatherers. Of course, a good practice of Technology Surveillance can help increase our tacit knowledge for taking the most appropriate decisions [5]. This is important for executives [6] but it should also be important for policy makers.

The aim of this paper is to collect the most significant facts on Energy Markets and Energy Technologies in the current times, in order to see if they can merge in a positive way towards Sustainable Development.

Three objectives will be considered for guiding this prospect: 
- To maximize the integral energy efficiency, i.e., to use energy from the primary source to the final application through the most efficient ways.

- To minimize the total cost of the new Energy sector.

- To minimize the total emission of greenhouse gases. It is obvious that these three goals can be incompatible, and a trade-off should be adopted in specific cases. Moreover, energy policies are established by each country, and the global approach has really to be pursued as the sum of individual country contributions. Besides that, there are huge uncertainties on the evolution of the markets and the actual performance of the technologies, and some of the forecasts can simply fail. In that case, an updating exercise could be done to try and find a new pathway towards the ideal goal described by the former trilogy.

In next section, the current relevant facts which drive this analysis are briefly introduced, particularly in relation of new technologies for electricity generation. Section 3 is devoted to Shale Gas, as a new market which can have a first order consequence: its price should not be related to that of oil. Section 4 deals with the Electric Vehicle (EV), which represent a new degree of freedom in our optimization process (if they really become a commercial product at large). Next section will analyze the merging of the new Electric sector with the EV, with the hydrocarbons being used in a different but fundamental way than today. The result will be assessed from the point of view of Sustainable Development in Section 6. Section 7 points out that such a re-structure would open a new macro-economic cycle with a lot of new opportunities for energy corporations. Finally, conclusions are proposed from this analysis about how to contribute to the making of the new Energy sector.

\section{A Brief Recollection of the Recent History of Our Energy}

The evolution of Energy in the second half of the $20^{\text {th }}$ Century was dominated by two types of facts, which could be classified into action and reaction. As action forces, we find Technology, on the one hand, and governmental Policy, on the other hand. As reaction forces, Market Inertia and Sources Scarcity (mainly due to political control) appear as retardant agents in this evolution.

Corporations dominating a specific Energy sector are not prone to stimulate changes, unless they go in the direction of consolidating such domination, which is a rare trend. Most likely, new degrees of freedom in the market at any level (from generation to final commerce) create more competitiveness in the system, and old dominations tend to disappear; and new ones can complement them. Of course, any corporation well rooted in the field of Energy tries to develop or acquire some of the emerging technologies which will likely dominate the following business cycles. These attempts have a very limited rate of success. Moreover, it seems there are fields of specialization, and corporations with strong positions in Oil Industry do not participate in Electricity and the opposite as well: main electrical utilities had very little involvement in Petroleum. Exceptions are true, but not with key players.

Specialization became more evident after the Oil Crisis of 1973 and 1979, as they produced a strong polarization of the consumption of oil products (gasoline, kerosene, and diesel) towards transportation. So to speak, oil was too expensive for electricity generation, which could be made with other sources, notably coal and nuclear, at a really moderate cost. On the contrary, the only primary source of energy able to provide the type of fuels suitable for thermal or internal combustion engines was Oil, and the actual lack of competitiveness in that field has kept Oil at the very top of the Energy domain [7].

The global situation started to change with the rapid and successful deployment of gas-fired combined cycles (GCC) in the 90's. Hydrocarbons were back again in the electricity production industry. At the same time hydrocarbon were part of the chemical embodiment supporting oil refining: $5 \%$ of the total natural gas consumption goes to hydrogen production for cracking long molecules of oil hydrocarbons for producing more valuable goods (as gasoline). Even more, in a few countries, as Italy and Argentina, natural gas became an ordinary fuel for automobiles, which was a fresh start of a competition that never reached a minimum drive for global expansion in order to be actually meaningful; unlike GCC, which expanded rapidly $[8,9]$.

It is worth pointing out that the unique case of China in the years around the turn of the Century, with its enormous electricity generation expansion, was based on coal [7]. It is also true that coal remained a main option for many developing countries, with small emission rates of $\mathrm{CO}_{2}$ per person; but most of the post industrialized countries move to GCC, notably in Europe, and particularly in Spain [9]. In Spain the installed capacity of GCC jumped from 0 in 2001 to $25 \mathrm{GW}\left(10^{9} \mathrm{~W}\right)$ in 2010 . Most of the plants were decided in years of buoyant economy, before 2007, and the total capacity installed in Spain grew quite a lot, from $54 \mathrm{GW}$ in 2001 to 85.5 in 2007 and 98 in 2010. The increment in last two years, arriving to $102 \mathrm{GW}$ in 2012, was mainly due to renewable energies (RE), notably Wind, Photovoltaic and Solar Thermal. This phenomenon is also relevant to the quest for Sustainable Development, but it is worth underlying now the tremendous speed of the deployment of GCC in the first decade of this Century in Spain, where electricity consumption was growing very fast. Between 1998 and 2003 the average electricity consumption rose from 5 to 5.5 
MWh $\left(10^{6} \mathrm{Wh}, 1 \mathrm{Wh}=3600 \mathrm{~J}\right)$ per capita in the so called EU-27, while the numbers for Spain were 4.1 and 5.3. These figures dominated the following expansion of the electricity industry, but the evolution did not keep that trail. In 2008 the average for the EU-27 was 5.75 MWh, and for Spain, 5.85. Values have remained flat for the past 5 years [10].

Two reasons converged for that move towards GCC plants in Spain and the European Union (EU): in a liberalized market, which was the dominant case in post industrialized countries since last years of $20^{\text {th }}$ Century, GCC offer a set of economic advantages that will be briefly explained right now; and GCC was also offering a much better figure in relation to Global Warming: depending on the efficiency, a GCC emits between 0.35 and $0.4 \mathrm{~kg}$ per $\mathrm{kWh}\left(10^{3} \mathrm{Wh}\right)$ generated; while a conventional coal-fired power plant releases around $1 \mathrm{~kg}$.

Techno-economic advantages are:

- Small specific investment, of the order of $700 € / \mathrm{kW}$.

- Repetitive projects. A high fraction of the plant is the same. This implies short construction times.

- Very flexible operation, particularly in the gas turbine; and also in optimizing the joint operation of the cycles according to needs for grid regulation.

The appeal of GCC was so high that too much capacity has been built in a short period in many countries, as can be said about Spain, where the numbers of full power equivalent working hours was less than 1500 in 2012 [9].

In an ordinary accountancy for current economic indicators, the annual fixed cost for GCC is about $8 \%$ of the specific investment, which means $56 € /$ year $\mathrm{kW}$. With 1500 hours a year, the contribution of the fixed cost to the cost of electricity is $3.75 \mathrm{c} € / \mathrm{kWh}(1 \mathrm{c} €=0.01 €)$. From some viewpoints, this value can be considered as too high, because it would decrease with a higher number of operating hours. However, the main part of the generation cost will be the fuel cost, which will depend on the international gas market. For many decades, gas price was proportional to oil price, with an index that will be considered in a following section, and has undergone a peculiar, somehow unexpected evolution. This fact explains that most of the GCC power plants in Europe (and specially in Spain) are operating with long term contracts with gas prices around or above $8 € / \mathrm{GJ}\left(10^{9} \mathrm{~J}\right)[11]$. Taking into account the average efficiency of GCC, this means a fuel cost close to $5 \mathrm{c} € / \mathrm{kWh}$. Adding the fixed cost plus operation and maintenance, the total cost would vary from $9 \mathrm{c} € / \mathrm{kWh}$ for a low number of working hours (1500 a year) to more acceptable values of $7 \mathrm{c} € / \mathrm{kWh}$ for 3500 hours. These are the values of reference for an analysis largely based on the Spanish case, which fully depends on natural gas imports [11], and they are higher than the current price of the liberalized market, which is the range 4 - $5 \mathrm{c} € / \mathrm{kWh}[12,13]$.
Spain is also an outstanding case on Renewable Energy Sources (RES) which will be analyzed later on.

\subsection{Sustainable Development}

The consolidation of Sustainable Development and the fight against Global Warming as main guidelines in International and Environmental policies produced the Kyoto Protocol as a tool based on quotas for restricting greenhouse gases emissions. Besides that line of action that was very simple in conception and very difficult in implementation, some countries, notably the United States under Bush Jr.'s Administration, started some technological initiatives which would convey a reduction of $\mathrm{CO}_{2}$ emissions, as Carbon Capture and Sequestration [14], the Hydrogen Economy and the Hydrogen Electric car with fuel cells [15] and the Nuclear Generation 4 Forum [16]. Although some laboratory advancements have been carried out, the practical effect of those initiatives on the Energy industry has been negligible so far, because all the initiatives were research programs aiming at long term results.

The case was different with shale gas, started in 2005 in Texas as a private activity mainly [17-20], which has commercially exploded under Obama's Administration, with very little political and environmental opposition [21]. Moreover, there are public approaches from the USA to China and Poland to stimulate shale gas extraction in those countries. Indeed, shale gas has become global [22].

This activity is considered by many as an environmental threat, mainly because of the possibility of uncontrolled methane emissions [23] and aquifer contamination. Hydraulic fracturing or "fracking" of the shale rocks is perceived as an aggressive operation for the environment [24].

In spite of said risks, which have not been properly featured so far, shale gas or unconventional gas has blossomed as a successful industry [25,26]. It has also been successful from an economic point of view, because it has stabilized international gas prices and has disconnected the gas price from the oil price, which is a fact that can have extraordinary consequences for the future of the Energy Industry [19].

For many decades, scarcity of energy sources was a dominating fact in this industry, absolutely dominated by producing countries, which in turn were not very active in fostering new technologies. In the last years, this fact is shrinking, except for transportation applications. Nevertheless, technology is introducing new perspectives also in that field, as will be analyzed later. It cannot be said that energy sources are no longer a problem, because Energy will always be limited by resources formally speaking, but this limitation could not be so critical in the future. The revival of coal, in China and other countries, 
the enlargement of gas reserves by the rise of unconventional gas and the modest but operative start of main RES have changed the scenario. The trail has been paved for more dramatic changes to happen in the direction of Sustainable Development. Of course, some environmental concerns on shale gas have to be clarified, and some controversies are already in the political arena and in courts $[27,28]$. Lessons learned from the pioneers in this subject are essential to that goal [26], and they will get higher degree of confidence as technology improves $[25,29]$, and surveillance measures are to be implemented.

Official prospects, particularly those exposed in the World Energy Outlook (WEO) [8] by the International Energy Agency (IEA) (particularly, in edition 2010) have not yet recognized that something is changing quite soundly in the global Energy sector, although the change is not yet worldwide, but initiated in a few countries with advanced technology and own resources as the USA, or countries without fossil fuel significant reserves, as Germany, Denmark and Spain, who have been very active in promoting the first phase of RES deployment. A second phase is needed now to cut their costs and make them competitive with conventional ways to generate electricity.

\subsection{The Onset of Renewable Energies for Electricity Generation}

Biomass (firewood) is a traditional example for presenting RES as natural occurring phenomena without any inherent capability to support and launch an industrial revolution. In fact, all RE [30] were already on Earth before the First Industrial Revolution, which was based on coal and steam engines, including those embarked in ships and railways; which rendered obsolete some renewable ways of travelling, as sail ships. Moreover, countries that still basically depend on firewood as a main source of energy show a very modest wealth [7,31].

In spite of these facts, there are some RES proponents who think that a New Industrial Revolution is possible based on RES [3], and those proposals should be analyzed in full perspective, starting from the fact that RE in general have a very low value of energy intensity (measured in energy per unit surface, for instance) and not all sites are good for exploiting them. Just the contrary, RES need specific sites for being profitable, and it is true that in many cases those sites are far away from big consumption centers, which is to some extent a drawback, but not a showstopper.

The evolution of RES for electricity generation has been relevant in some European countries, particularly Germany, Denmark and Spain. If hydro resources are not taken into account (because of some controversies on the effects on the environment) the numbers on Table 1 show the installed capacity of RES [10] for three countries in 1998 and 2008.

Most of the RES capacity corresponds to wind power, with a small contribution of biomass and natural waste. In the case of Spain, Photovoltaic (PV) and Solar Thermal have also a share in this figure [32-36]. In fact at the end of 2012, the installed capacity of RES in Spain is given in Table 2 [6], with some additional important data.

The annual number of operating hours is an important data for the cost of electricity, as we saw in the case of gas, with a main difference between both cases: RES do not consume fuel (this is not true for Biomass, in principle; but it is actually true if it is taken into account that the fuel used in this case is a sort of waste, and it is therefore of zero value). On the contrary, the investment cost is higher, and this is where an additional effort is needed.

It is worth pointing out that RES produce some second-order or collateral effects in the Electricity generation system [37-39] and they cannot be disregarded when making decisions on the types of plants to be built in a given period, if some objectives must be fulfilled. One of these effects is the reduction of the spot price of electricity when RES have a sizeable share of generation power, because the total power needed from the conventional plants is lower, and it must be remembered that those plants get permission to operate if they are cheap enough to be below the cost of the last plant which meets the demand.

Another collateral effect is the need of back-up power, which is usually supplied by GCC, which however have a decreasing number of operating hours. This effect produces an increase in the GCC generation cost. As the last plant joining the Spanish grid typically is a GCC, said increase in cost is mostly transferred to the market which is an opposite effect.

Table 1. Renewable energies installed capacity for electricity generation.

\begin{tabular}{ccc}
\hline Country & GW in 1998 & GW in 2008 \\
\hline Denmark & 1.8 & 4.2 \\
Germany & 4.5 & 35.6 \\
Spain & 1.1 & 21.0 \\
\hline
\end{tabular}

Table 2. Renewable energies installed capacity for electricity generation in Spain, 2012-12-31.

\begin{tabular}{ccccc}
\hline RES & $\begin{array}{c}\text { GW } \\
\text { year end }\end{array}$ & $\begin{array}{c}\text { GW } \\
\text { average }\end{array}$ & $\begin{array}{c}\text { Energy } \\
\text { TWh }\end{array}$ & $\begin{array}{c}\text { Hours } \\
\text { per year }\end{array}$ \\
\hline Wind & 22.2 & 22.0 & 48 & 2200 \\
Biomass and wood & 0.95 & 0.95 & 5 & 5000 \\
Photovoltaic & 4.2 & 4.0 & 7.9 & 2000 \\
Solar thermal & 1.9 & 1.4 & 3.5 & 2500 \\
\hline
\end{tabular}


Decisions on the type of RES to be fostered or implemented in a region, country or continent is a multi-a ttribute process [40-42] where many variables can be aggregated, but the most convincing criterion is the cost-priority rule [42]. It is mandatory to speed up the learning curves of these sources of energy instead of keeping the subsidies, which are only justified if they help reduce costs.

It is not clear if the promotion policies chosen by the countries actually engaged in this development have been the optimum ones, but the result shows a clear tendency for cutting costs, particularly in wind power [43], but also in Photovoltaic.

The price evolution of PV systems has been recently analyzed for the USA market [44] and reported in a document which is a good guide for further prospects into the future. This evolution is captured in Figures 1 and 2.

These two figures illustrate quite clearly two main facts: cost reduction as technology becomes mature and industrialized; and the main components of cost, which of course are the main subsystems with own functionalities in PV: the solar module, the inverter, and the Balance of System, which is the set of structures, cables, tracking and any other ancillary hardware needed to operate the system. It has a role in PV similar to the Bal-

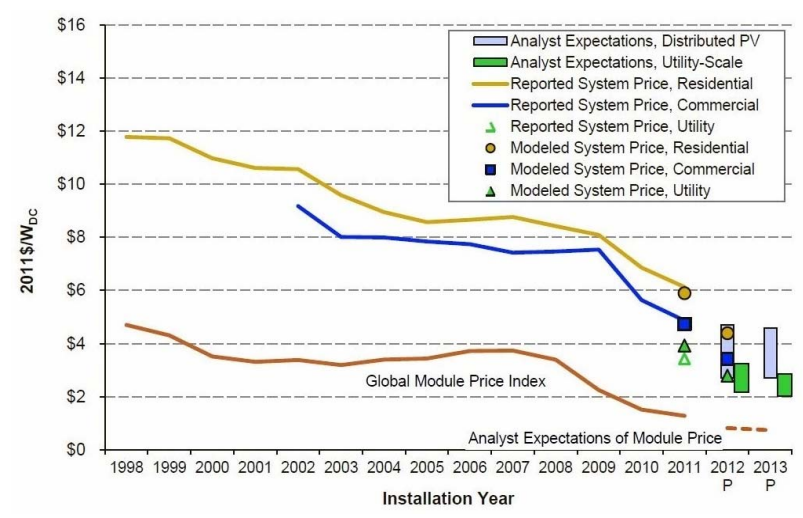

Figure 1. PV system cost [44].

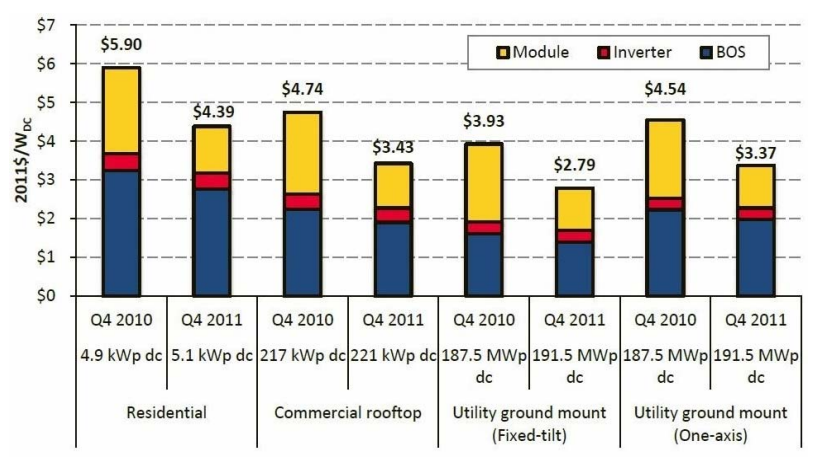

Figure 2. Bottom-up modeled installed PV system prices by sector, Q4-2010 and Q4-2011 [44]. ance of Plant (BOP) in thermal power plants, although the BOP for Concentrated Solar Power (CSP) (also called Solar Thermal Energy) is more complex, because it embodies a thermodynamic cycle, usually a water/ steam Rankine cycle.

CSP evolves somehow behind PV because a series of reasons which are out of the scope of this paper, although they can be summarized into one fact: a PV plant project is much simpler and takes less time to build than a CSP project. It is worth pointing out that PV does not need plant cooling, which is necessary in thermal power plants, and it is usually made by a stream of water; and there is not abundant water in hot, sunny places, which means that many CSP plants in the future will have to be air-cooled (which implies lower energy conversion efficiencies [45]). On the contrary, CSP has the main advantage, over PV and Wind Power, of having an inherent way to store energy, which is Thermal Energy Storage (TES) $[46,47]$. Heat can be stored in molten salts tanks, and steam can be generated out from this heat when needed, for instance after sunset. Moreover, CSP plants can be used for regulating the high voltage grid and the system as a whole, because of their thermal inertia, which still becomes bigger when TES is accounted for. Any grid, and the total electricity system hanging from it, must be regulated in power, voltage and frequency, what will be a challenge in the future, if the world becomes more dependent from electricity.

CSP economics [48] is still in the very first phase of consolidation, and costs are still higher than PV, although it seems possible to reach values of specific investments close to $2.5 € / \mathrm{W}$ in plants without TES and 3.5 $€ / W$ with TES. In the former, the number of operating hours per year could be 2500; which goes up to 3500 or even more when TES is introduced. Very likely, CSP will have to embody TES in the future because it is a feature of very high value for fitting demands needs and for grid regulation. It could be more expensive than PV at peak hours, but it will have the right answer to demand needs in the absence of Sun.

In summary, RES for electricity generation are already a technical reality with a main drawback-the cost. However, they have already achieved very modest levels of specific investment. In Section 5, it will be seen that those values would yield competitive generation costs if the interest rate is low and/or environmental effects are internalized in fossil fuels.

\subsection{Renewable Energies for Transportation}

A different field of RES is biofuels for internal combustion engines. Reference [49] considers Biofuels will be the natural substitute for petroleum products. Biofuels [50,51] will mainly stem from sugar crane for making ethanol in a first stage, followed by corn for the same 
objective, and soy for making diesel, with a long term quest for cellulosic biofuels.

One of the reasons for considering biofuels as substitutes for hydrocarbons is that they require a small transformation of the infrastructure of the whole Automobile Industry (mainly Light Duty Vehicles, which will represent an inventory of 300 million cars in the USA by 2035). Reference [49] considers that the retardant character of the existing industry will have a dominant effect in reshaping the future of Energy, and car makers will adhere to internal combustion engines, which can admit natural fuels with some limitations.

Indeed, gasoline engines have already some flexibility to accept small percentages of bio-ethanol, and full flexfuel engines will run on E85 (85\% of ethanol). However, a complete analysis should put more emphasis on the problems Biofuels are already causing in Brazil and elsewhere [52-55].

At first, the overall picture of energy values related to this problem seems to indicate that a "Biofuel industry" can be developed worldwide without too much distortion of the current agriculture activities; but a deeper analysis points out deeper problems. It is estimated that the total solar energy captured by living beings of all kind amounts to $3000 \mathrm{EJ} /$ year $\left(10^{18} \mathrm{~J} /\right.$ year $)$, which is about $0.08 \%$ of the total solar radiation impinging on Earth, and it is six times as large as the human demand of primary energy, which is close to $420 \mathrm{EJ} /$ year (circa 10 billion $\left(10^{9}\right)$ tons of oil equivalent (toe) per year; where 1 toe $=41.87 \mathrm{GJ} \approx$ 7.3 barrel of oil equivalent). Accounting for primary biomass consumed as an energy good, we could add circa 40 EJ/year.

Oil products amount to a little less than $150 \mathrm{EJ} /$ year, which is about $5 \%$ of the total biomass capture of energy. Therefore, the disturbance produced by this substitution seems acceptable, but the full picture contains other elements which must be accounted for. The energy content of the biomass for our feeding is slightly higher than one twentieth $(1 / 20)$ of the energy we consume for other uses, namely $23 \mathrm{EJ} /$ year. This value must be taken as the real reference for any man-made intrusion in the biomass world with the goal of producing new types of commercial products (some genetically modified cellulosic plants, for instance) or already known products (sugar cane, soy beans, palm oil) at a scale much larger than the total current effort for our food.

If former numbers are compared, one finds that the substitution of one third of the oil products by biomass products would require twice as much as the current activity for food. Of course, this is not an impossible quest, but some warnings should be expressed on the potential distortion caused in agriculture, and the potential impact caused in the environment (particularly, in some privileged ecosystems of high biological vitality). Besides that, the cost will be much higher than those of oil products, measured in terms of energy. The economic problem can be epitomized as follows: we pay for food a value which is several times the value we pay for transportation, even if all the very heavy taxes on oil products are accounted for. The customer price of gasoline or diesel is about $2 € / \mathrm{kg}$, and the price of a really modest wine could be similar, with a strong difference in the Low Heating Value (LHV) which is $40 \mathrm{MJ} / \mathrm{kg}\left(10^{6} \mathrm{~J} / \mathrm{kg}\right)$ for the gasoline, and $30 \mathrm{MJ} / \mathrm{kg}$ for the ethanol, which in turn is $12.5 \%$ of the mass of wine, which means that LHV referred to wine would be less than $4 \mathrm{MJ} / \mathrm{kg}$. In energy terms, we find a heating value of $20 \mathrm{MJ} / €$ for gasoline, and less than $2 \mathrm{MJ} / \mathrm{kg}$ for ethanol from grapes. If taxes were eliminated if the comparison, the factor would jump from 10 to 20. It is true that there are other agriculture goods that could be more efficient than grapes for making alcohols and other fuels, but the difference in efficiencies is of tens per cent, and therefore negligible in the comparison with oil products.

It should be kept in mind that total ethanol production is about $111,300 \mathrm{~m}^{3}$ per day $(700,000$ barrels per day (bbl/d)) and biodiesel production is close to $8000 \mathrm{~m}^{3}$ per day $(50,000 \mathrm{bbl} / \mathrm{d})$. Reference [51] provides 2004 production values, but they have increasing since. These figures are much lower than the final consumption of gasoline, which is about 20 million $\mathrm{bbl} / \mathrm{d}$, and diesel, which is slightly higher, 21 million bbl/d. Although it is claimed by biomass proponents that they would require the smallest modification in automotive infrastructure as compared with other alternatives, Biomass could produce a huge perturbation in agriculture, forestry and the cycles of natural nutrients; and would also entail a tremendous increase in the fuel price.

Technology evolution in this field has been boosted by suitable policies implemented in several well-developed countries. The EU directive on RE, for example, requires that renewables should account for at least $10 \%$ of the energy used in traffic and transport by 2020 . National legislation in Finland has targeted 20\% content by 2020 , and legislation in the US will require $20 \%$ content by 2022. All these figures originally meant biofuels, although other alternatives, as electric cars charged with electricity from RES, could also be accepted now to meet that goal. The EU is studying how to define the guidelines for financial incentives for clean and energy efficient vehicles [56] and this effort seems to be much more open to innovation than DOE's Annual Outlook [49] but does not make any attempt to characterized the emerging alternatives and to make a priority list taking into account the trilogy of objectives towards Sustainable Development: highest energy efficiency; low economic burden; minimum greenhouse gases emission rate. Reference [56] asks for avoiding discrimination among technologies in 
the promotion policies, to allow the technologies to evolve according to their own potential. This point will be timely treated in the section considering the merging among technologies to produce the best scenario according to the triple objective already defined of energy efficiency, financial viability and environmental quality.

\section{A New Paradigm: Gas Price Not Indexed to Oil}

The evolution of the price of natural gas in the international market since 2008 is incredibly stable, particularly in relation to oil crude prices, as shown in Figure 3. Measured in terms of energy $(1 \mathrm{MMBTU}=1.055 \mathrm{GJ})$ the ratio between oil price and gas price was around 2 along the 1980's, went down to less than 1.5 around 2000, then went up a little, and started soaring around 2008, because oil crude doubled the price in less than 3 years, and gas price remained as it was. The price ratio has reached peak values close to 10 , and mid-term values of 6 , so pointing out that gas price in the spot market not indexed to oil, as it happened most of the time since the oil crisis of 1973 up to now. Figure 3 presents the historical price of oil and gas on energy terms and the price ratio of both commodities.

Such price stabilization is not spurious, but caused by a well define fact: the unconventional gas recovery started in the USA after several decades of improving technologies, although the driving forces were not coming from technology, but from policy. On the one hand, it was urgent in the USA to reduce somehow the share of coal in electricity generation because it was the main cause of $\mathrm{CO}_{2}$ emission in the USA; on the other hand, the economic crisis could worsen if energy goods jumped in price. Against this menace, a new technology was able (since 2005, in Texas) to extract shale gas at a low cost and very close to the consumer.

This new technology has expanded under president Obama's Administration, and it has found very few and

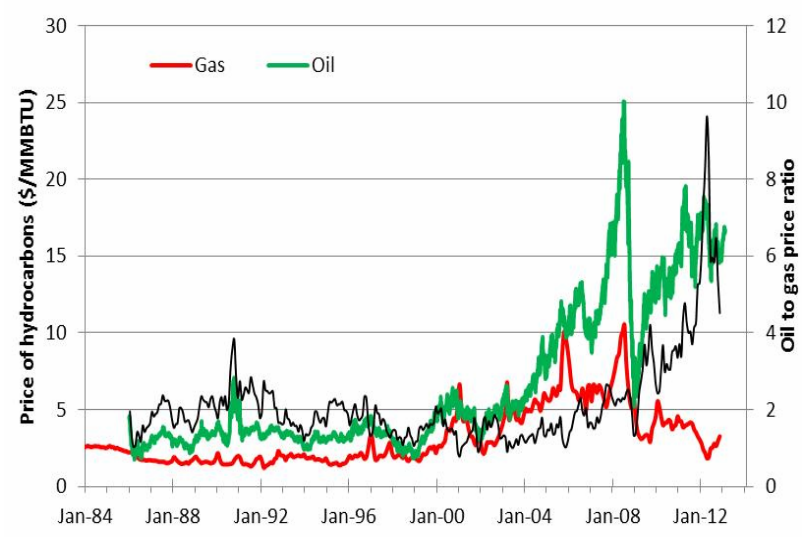

Figure 3. Evolution of oil and gas prices in the spot market. very frail opponents so far. In North America, only Quebec (Canada) was clearly against unconventional gas extraction, by environmental reasons mainly [27,28].

In Europe, unconventional gas prospects and extraction permits go much slower than in the USA, and controversies on the global effects of these techniques are still under question mark. Moreover, it seems that both the European authorities and the energy agents do not consider the case of unconventional natural gas as a part of the quest to Sustainable Development, in spite of a strong coincidence between the effects of unconventional gas extraction and the energy scenario needed for implementing Sustainable Development. Additionally, the post-Fukushima German government decision to abandon Nuclear Energy will convey strong interest in shale gas, not only in German territory but also in Poland [57], which seems to be the country in Europe with the highest reserves, inside a global framework that can be qualified as "a new era of natural gas abundance" [58]. Another important example is Algeria [59] a traditional gas supplier to southern European countries, where shale gas reserves are considered to be very modest.

It is worth recalling the evolution of the gas industry worldwide and the evolution of the international trade, which is still to explode as a market [11]. This can be seen through the figures presented in Tables 3 and 4.

International trade is made basically by pipelines but liquefied natural gas is gaining share. It was only $22 \%$ in 2005 , and reached $30 \%$ six years later.

In this new era continues for some decades as expected, the traditional picture of ratio reserves over annual consumption will change quite a lot. A historical back look to these ratios is presented in Table 5. New gas ratios can be over 100 years, which has already inspired another way to substitute for, or complement, oil products for transportation, namely gas to liquid (GTL) techniques [60]. The concept is not new, and could be interpreted as a synergic way of exploiting hydrocarbons. Methane must lose hydrogen atoms for becoming liquid, and heavy and long hydrocarbons need hydrogen atoms for splitting the long carbon chain into shorter hydrocarbons, better suited for combustion.

The typical value of 60 years for conventional gas can

Table 3. Annual production of natural gas, in $\mathrm{bcm}\left(10^{9} \mathrm{~m}^{3}\right)$.

\begin{tabular}{ccccccc}
\hline Year & 1970 & 1980 & 1990 & 2000 & 2010 & 2011 \\
\hline Volume & 1020 & 1490 & 2020 & 2440 & 3220 & 3330 \\
\hline
\end{tabular}

Table 4. Annual amount of international trade of natural gas, in bcm $\left(10^{9} \mathrm{~m}^{3}\right)$.

\begin{tabular}{ccccc}
\hline Year & 2000 & 2005 & 2010 & 2011 \\
\hline Volume & 630 & 860 & 1015 & 1077 \\
\hline
\end{tabular}


Table 5. Evolution of reserves-to-consumption ratio of oil and gas (excluding shale gas).

\begin{tabular}{ccc}
\hline Year & Oil (years) & Gas (years) \\
\hline 1975 & 30 & 50 \\
1985 & 32 & 56 \\
1995 & 42 & 66 \\
2005 & 40 & 61 \\
2011 & 48 & 61 \\
\hline
\end{tabular}

be multiply by a factor 2 if shale gas is included. The factor can be much higher if other unconventional sources, as methane clathrates, are also included.

Natural gas still has other news for the future, notably in relation to clathrates, or gas hydrates, which are crystalline solids resembling ice, with a molecule of gas (methane, in most of the cases) in the center of the cage-like structure [61-65]. Clathrates are stable only under certain conditions, which also depend on the gas composition, salinity and the existence of other molecules acting as pollutants, but the main body of clathrates is made up of methane and water. At $278 \mathrm{~K}\left(5^{\circ} \mathrm{C}\right.$ or $\left.41 \mathrm{~F}\right)$, a pure methane hydrate is formed at $4 \mathrm{MPa}$ (41 atm or $580 \mathrm{psi}$ ). If taken to atmospheric pressure, the hydrate dissociates to yield $160 \mathrm{~m}^{3}$ of methane and $0.8 \mathrm{~m}^{3}$ of liquid water per original cubic meter of hydrates.

The content of organic carbon on Earth in thousands of Gt $\left(10^{15} \mathrm{~kg}\right)$ is estimated as follows $[61,62]$ :

- Gas hydrates (total = onshore + offshore) 10 ;

- Standard fossil fuels (coal, oil and gas) 5;

- Soil 1.4;

- Dissolved organic matter 1;

- Land biota 0.88 ;

- Peat 0.5.

It goes without saying that removing gas hydrates without a suitable technology could cause a tremendous greenhouse effect disaster in the atmosphere, and such a technology is not available yet. Moreover, an accurate knowledge of the properties of given clathrate formation is needed, in order to know the stabilizing mechanisms, for not to disturb them outside the extraction domain.

Nevertheless, there can be gas hydrate sites easier to explore and exploit, for instance in the permafrost [66]. Moreover, the physic-chemistry of clathrates is improving with research and technology development, and they can be considered not only as a source of energy, but as a way to storage natural gas [67], forming hydrate molecules with ordinary methane and water.

In summary, methane industry seems to have extraordinary possibilities for our future. In this line, shale gas is already a reality that has produced a tremendous impact on the gas market in a very short time. Indeed it has been so short (since 2005) that most of the long-term contract existing in this field could not be modified, but new ones will have to be redressed. Price stabilization in the spot market with a value one order of magnitude below that of oil, in energy terms, is not only a clear signal for short-term economics, but a hint of a deep change in the Energy sector.

\section{A Potential Paradigm: Electric Vehicle}

Ref. [8] considers that the total number of vehicles in the planet will double in 2035 the current number of vehicles (1700 million in total, accounting for all types). A similar projection is given for the USA in [39] with 300 million vehicles for that year (plus lorries and buses).

According to WEO, oil production will grow from 87 to 99 million bbl/d, which seems to be the approximate value of the "oil peak". Of course, oil prices are foreseen at high level, well above $100 \$$ per barrel $(\$ / b b l)$ in 2011 currency terms. In any case and with any price, there will be an important shortage of fuel for transportation, and this is the key point to try and reshape the Energy sector.

At least four alternatives can be considered to that purpose:

- Biofuels;

- Natural Gas in engines;

- GTL;

- Gas to electricity.

Some attempts have been made to characterize pros and cons of different energy alternatives [68] but the objectives identified in this paper seem closer to the needs of Sustainable Development and to the needs for finding new economic incentives to go out of the crisis. So, each alternative will be assessed according to those terms.

\subsection{Biofuels}

Biofuels can be considered as a continuation of the current situation, without needing new types of cars, although some changes in the engines are advisable, because the LHV of biofuels is lower than those of their mineral counterparts (gasoline, diesel).

This is a real problem, which hides one important drawback, namely the low energy efficiency of internal combustion engines, because of the limitation in the compression ratio, which in turn limit the working temperature. For gasoline engines with compression ratios of 10 the average efficiency can be estimated in $23 \%$; and diesel engines with compression ratios close to $20 \%$ can reach $28 \%$. And this drawback makes things worse with the main drawback, which is the great distortion a demand like that can cause in agriculture, and the enormous increase in price associated to natural ways to produce fuels for combustion engines. It was seen in Section 2 that the energy price of biofuels is much higher than the energy price of oil products, which would make the oil crisis worse. Nevertheless, the main drawback would not be price, but interference with agriculture, because the cur- 
rent oil consumption is six times as large as the energy content of our food. Therefore, land and resources devoted to such a new activity that could be called "agricultured fuels" would be enormous, and almost impossible to imagine, with environmental impacts impossible to evaluate because the current scale of agriculture activity is not meaningful for understanding such a change.

The example of Spain [69] could be used as an average country in rainfall and sun, which are two essential factors for biomass. Its land surface is $5 \times 10^{11} \mathrm{~m}^{2}$ and about $10^{11}$ $\mathrm{m}^{2}$ are cultivated land, with a modest productivity because of the modest water availability. Note that $0.001 \mathrm{~kg}$ $(1 \mathrm{~g})$ of wheat grain needs about $1.2 \mathrm{~kg}$ of water to grow. Of course there are other plants, as Cynara Cardunculus, with lower water requirement, but even so the average productivity per year is about $1 \mathrm{~kg} / \mathrm{m}^{2}$. With a LHV of 10 $\mathrm{MJ} / \mathrm{kg}$, it means an energy areal density of $10 \mathrm{MJ} / \mathrm{m}^{2}$.

Current annual consumption of oil products for combustion engines in Spain [70] is close to 40 million tons (Mton, 1 Mton $=10^{9} \mathrm{~kg}$ ) a year (5.5 Mton of gasoline; 31.5 Mton of diesel. Aviation kerosene is about 5.5 Mton, too, and there is still other 12 Mton for other products, both lighter and heavier). Just taken into account gasoline and diesel, the energy content corresponds to $1.6 \times 10^{12}$ $\mathrm{MJ}\left(10^{6} \mathrm{~J}\right)$. If we recall the former biomass figure of 10 $\mathrm{MJ} / \mathrm{m}^{2}$ per year, the required land to produce that level of energy would be $1.6 \times 10^{11} \mathrm{~m}^{2}$, which is about one third of Spain's total land. Note that one fifth is already cultivated, with a share in the Gross Domestic Product of $4 \%$, which represents about $40 \mathrm{~b} €\left(10^{9} €\right)$. This value is commensurate with the total final price of oil products for automobiles, which is about 60 b€ (including taxes). In other words, Biofuels would likely be as expensive as oil.

\subsection{Natural Gas for Engines}

Taken into account the data about gas reserves and price, this line seems cheaper than the previous one by a large factor, but it has a main technology drawback, which is methane storage and refill. This is not a problem for city buses, for instance, because the can refill at night in a lengthy isothermal process. If the pressure tank is filled very rapid, compression becomes adiabatic, gas becomes hot, and the amount of mass is much lower than in the isothermal compression.

The alternative for cars is changing the tank. The operation is not very complex, but the weight of the contained gas is about $3 \mathrm{~kg}$ for a $0.02 \mathrm{~m}^{3}$ (20 liter) tank, which means about $10 \mathrm{~kg}$ for 3 tanks, and such a volume would give an autonomy five times lower than a diesel engine with a tank of $0.06 \mathrm{~m}^{3}$ (60 liters).

\subsection{Gas to Liquid}

A way to overcome the former drawback is to transform gas into liquid, and it has already been said that a synergetic process could be established between this transformation, which yields hydrogen as a by-product, and hydrocracking of heavy hydrocarbons, which needs hydrogen to break the long molecules.

This line would be the closest one to the current system, and the only factory to be changed would be refineries, which are industrial facilities where new processes can be installed without any big difficulty. The systems would be pretty much the same for the customers (and tax collectors) and the energy efficiency would be almost the same. Additionally, $\mathrm{CO}_{2}$ emissions would also be at a somehow lower level, but not much lower, depending on the share of original natural gas in the final mixture put in the tank. Pure methane would produce $70 \%$ of the $\mathrm{CO}_{2}$ produced by very heavy hydrocarbons, with the same release of energy. Indeed, GTL can be considered the business as usual solution. However, it would not be so; because it could be cheaper and it would need a change in the refine process where many companies could find a niche for new activities.

\subsection{Electric Vehicles}

First of all it must be admitted that many prospect studies and some interpretations of current statistics do not consider the EV as a reality deserving first-class attention. In this variation, [8] considers that the share of EV would be rather small, and something similar happens with [49].

Indeed EV need further technology development, notably in the field of batteries [71-74], but the potential goal to be reached $[75,76]$ deserves a real first-class attention, particularly for corporations either in the side of car manufacturers or in the side of energy goods suppliers.

EV would imply a deep change in car manufacturing and in fuel market. EVs [77-79] have a powertrain totally different than internal combustion cars, although hybrid cars have both worlds embodied in the same unit. Nevertheless, the actual big change would happen with plug-in hybrids and full electric cars. Simple (or current) hybrids depend on oil products directly, while full electric depend on the electricity sector, where many generation technologies meet and compete, notably gas-fired power plants and main direct RES-wind and solar.

It is obvious that EVs would convey the largest financial needs because it implies the largest change both in car manufacturing and in energy supply to cars.

Estimates on that will be presented in next section. Of course, the feasibility of this alternative critically depends on batteries, and a sound evaluation of its potential development is out of the scope of this article, and it is likely to be too soon to make a valuable appraisal on this field.

The EU Commission's Staff Working Document, "Guidelines for financial incentives for clean and energy effi- 
cient vehicles", asks for not to induce any discrimination on the possible lines of research in this field. It is therefore very important to have a common unit for measuring the advancement of a given alternative towards the main objective, and this unit should be the $\mathrm{CO}_{2}$ total emission in a given system, taken into account the full system, not only the car itself. Of course, for local contamination problems, the unit of measurement would be the local emission rates, where full electric would be the best qualified.

Global (well to wheel) analysis of different technology scenarios point out that EV $[75,76]$ will offer the highest efficiency, and will minimize contamination in populated areas. As an illustrative case for this quest, we can consider that a good new vehicle of medium class will present in average an emission of $125 \mathrm{~g} / \mathrm{km}\left(1 \mathrm{~g} / \mathrm{km}=10^{-6}\right.$ $\mathrm{kg} / \mathrm{m}$ ). An electric car would consume around 0.14 $\mathrm{kWh} / \mathrm{km}$. This value will rise to 0.17 if the efficiency in charging the battery is accounted for. In Spain, an average value of $\mathrm{CO}_{2}$ emission in the electric generation system is slightly less than $0.4 \mathrm{~kg} / \mathrm{kWh}$; which means less than 70 $\mathrm{g} / \mathrm{km}$. The situation will improve if coal-fired power plants decline in activity (they generate $1 \mathrm{~kg}$ of $\mathrm{CO}_{2}$ per $\mathrm{kWh}$ ) and RES continue to increase their generation. As a reference, GCC produce between 0.35 and $0.40 \mathrm{~kg}$ of $\mathrm{CO}_{2}$ per kWh.

With a gas engine, a car can emit between 110 and 140 grams of $\mathrm{CO}_{2}$ per kWh. Should the gas be burnt in a GCC, an electric car fed with that electricity would emit (indirectly) between 55 and 70 grams of $\mathrm{CO}_{2}$ per $\mathrm{km}$.

From the point of view of a longer step towards sustainability, EVs are the most interesting alternative, and they also convey the highest efficiency in the system as a whole. On the contrary, they require more money to finance the transformation of an industry which is very well rooted in its methods and rules; which does not mean it is not sensitive to innovation and change.

\section{Merging Two Country Roads into a Single Highway: The New Electrical World}

Is there any news in the current energy scenario that could boost EV as the right solution for the future of Energy? The answer seems to be yes. Two reasons for it: the technical success of Renewable Energy Technologies in a first phase of deployment; and the onset of shale gas, and the gas abundance it conveys.

It is obvious that RES must reduce costs to become competitive with current generation costs, which are in the range of 40 to $80 € / \mathrm{MWh}[12,13]$. All three main RET (wind power, PV and solar thermal) could be below $100 € / M W h$ in sites with good meteorological values. Even in Spain, without extraordinary values in sun hours and winds, the result is quite positive, in the sense that the number of operational hours almost reaches the natu- ral availability values. This fact was shown in Table 2, where it is also seen that solar thermal has a higher load factor than PV (2500 hours instead of 2000) thanks to the TES system.

Energy storage is already a problem for the electric system, and it will become more complex as the installed capacity of RES increases. For the moment, at least in Spain (which has the highest sharing of RES in meeting the demand, in percentage) instead of energy storage, the complement to RES is GCC. Although the number of operational hours in 2010 was very low for GCC (1500) it still is the cheapest way to guarantee meeting the demand, because the GCC specific investment is quite low (around $700 € / \mathrm{kW}$ ) and the main part of the cost is the fuel, which has kept a very stable price in the spot market, once the shale gas joined the market.

The classical alternative for storage in the Spanish case was hydro-pumping, which received a boost 30 years ago, when most of the nuclear power plants were built, and excess of generation was expected at nights. In 1990, the hydro-power capacity was $2.5 \mathrm{GW}$ and was slightly higher in 2012, $2.75 \mathrm{GW}$ [9]. It is true that some nights, some of the wind farms have to be left idle because an excess of generation [39] but the alternative to build additional hydro-power stations is not attractive. An example of this problem was Karpathos Island in the Aegean Sea, where a hydro-station working by a cliff absorbs the excess of power of a wind farm of $5 \mathrm{MW}$. The case is well documented [80] and it is disclosed that the cost of the hydro-power complete station (including upper reservoir, penstocks, turbines and so forth) was three times as large as the cost of the wind farm (roughly 5 million $€$; while the former was 16 million $€$ ).

This example is not only relevant about storage, but about RES themselves. They are cheaper than conventional installations which were considered competitive 30 years ago (within a given pattern of consuming cheap electricity for producing later more expensive electricity, with a total loss of about $35 \%$ ).

If we look towards the future to try and find hints on evolution of markets and technologies, a key document [81] is the "Golden rules for a golden age of gas", elaborated by the IEA. This work is rather classical in methodology and does not open too much room for innovation, neither for RES nor for EV. However, predictions of electricity generation for 2020 are as indicated in Figure 4 [81], which presents for Europe a level of costs similar to the target of best RES, if learning curves keep their track. If the difference in energy scenarios among continents is kept as indicated in this figure, the interest in RE will also be very different, and the EU would have to increase their interest not only in RET but in regions with high potential in these sources of energy, as the Middle East and North Africa. Of course, a parallel line of sup- 
ply will rely on natural gas imports plus GTL expansion.

Ref. [81] gives little room is given to a revolution in automobile technology, and the forecasting on primary energy demand and electricity generation do not show big changes, as depicted in Figures 5 and 6. Nevertheless, a major share of gas and RE is foreseen in electricity generation, which is in line with the objectives proposed in this paper, although the IES study does not give too much credibility to $\mathrm{VE}$; which will cover a very small percentage of the 1.7 billion vehicles expected for 2035 , which means twice the current number. Some adjustments are needed to fit forecasting on the demand side and on the production side, because oil consumption will increase very little, and other ways of powering vehicles will be needed.

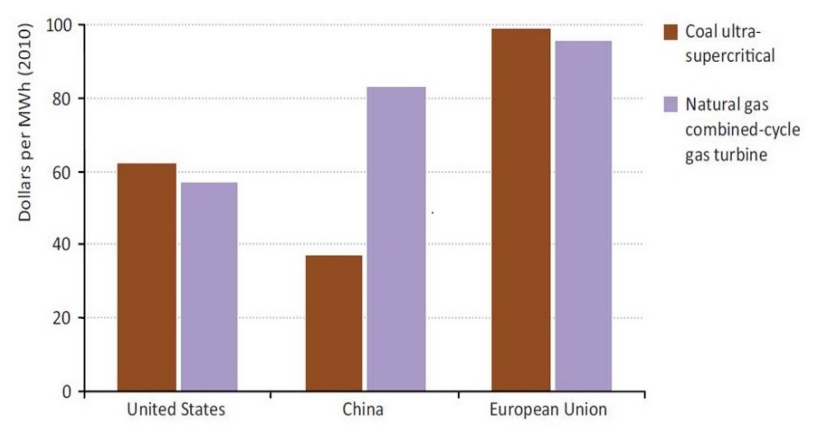

Figure 4. IEA estimates of electricity generation cost in 2020 [81].

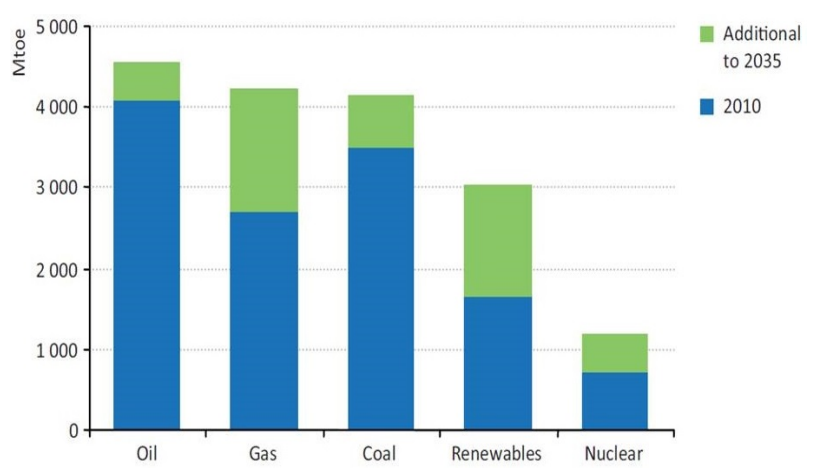

Figure 5. IEA estimates of primary energy demand [81].

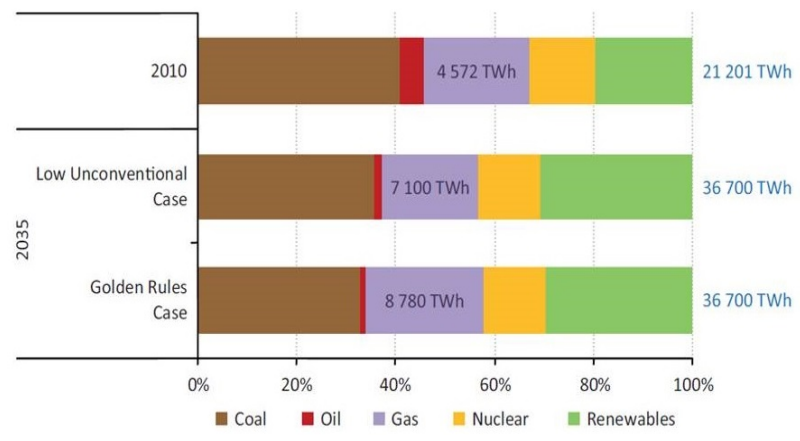

Figure 6. IEA estimates of electricity generation [81].
Similarly, new ideas (some of them, technology-based) would be needed to reduce and curb $\mathrm{CO}_{2}$ emissions; and the ideal situation would be reach such environmental objective with the most energy-effective scenario, because it could convey new types of economic triggers that would enhance economic growth.

A simple but systematic calculation will help clarify this proposal, particularly based on the case of Spain, with approximately 20 million vehicles and a total consumption of 40 million tons of engine fuel per year (as already presented) which means a final cost for customers of $60 \mathrm{~b} €$ which include a tax percentage of $50 \%$ approximately, and. In gross energy terms, the total annual consumption is $1.6 \times 10^{12} \mathrm{MJ}$, with an efficiency of $25 \%$, which means a net energy for powering the vehicles of $0.4 \times 10^{12} \mathrm{MJ}$. The total emission of $\mathrm{CO}_{2}$ is around 120 Mton. The amount of crude oil to yield the 40 Mton of fuels (mainly, diesel) consumed per year is around 55 Mton [70], or 410 million barrels, taking into account other products generated in refining, which are much less expensive than gasoline or diesel. With a crude price of $100 \$ / \mathrm{bbl}$, the total expenses in primary energy would be $25 \mathrm{~b} €$.

In $\mathrm{EV}$, the engine efficiency will be about $95 \%$, and the battery efficiency can be estimated in $80 \%$, although rapid charging will be less efficient than slow ones, which would be followed in filling stations were batteries could be replaced safely and rapidly. Another efficiency of $90 \%$ can be considered for distribution losses and internal consumption, so yielding a dispatching efficiency of 0.684 , which has to be multiplied by the generation efficiency close to $60 \%$ (although free spinning gas turbines with improved bottom cycles could likely reach $70 \%$ in the near future). So, a complete cycle efficiency of $40 \%$ is found, which represents a gross energy value of $10^{12} \mathrm{MJ}$ of gas (i.e. $27 \times 10^{9} \mathrm{~m}^{3}$, or $24 \mathrm{Mtoe}$ ), which is $60 \%$ of the reference case with oil. In $\mathrm{CO}_{2}$ emissions the corresponding value is 52 Mton, less than half the former value. Assuming a gas price of $6 € / \mathrm{GJ}$ (which is a value halfway between shale gas and current long-term contract) the total expenses in primary gas would be 6 b€, (i.e. one fourth of the expenses for crude). Of course we have to include here the conversion into electricity, the distribution, and so on. If current data for Spain's electricity system are used as a reference for calculating an average final price of electricity, we find that the total electric energy sold to customers is around $280 \mathrm{TWh}$ $\left(10^{12} \mathrm{Wh}\right)$, and the total income of the companies is about $28 \mathrm{~b} €$, which makes a value of $100 € / \mathrm{MWh}$. This is in agreement with data explained in Section 2 of this paper, which gives a fuel cost for electricity generation in GCC around $40 € / \mathrm{MWh}$.

The final price to customers would between 2.5 times larger, which also is a reasonable factor for an efficient 
electricity system. It must be noted that electricity has not a unique price, and differences between large industrial consumers and standard residents can be much higher than the values here indicated. Taking into account the average price of $100 € / \mathrm{MWh}$ for our calculation, this price has to be applied to the $0.54 \times 10^{12} \mathrm{MJ}$ electric energy sold as such, i.e., $0.15 \times 10^{9} \mathrm{MWh}$, which gives $15 \mathrm{~b} €$ of total expenditure by the customers.

It is worth noting the big change induced in the electric system by this technical revolution, because the market would jump from 280 to $430 \mathrm{TWh}$, an additional commercialization of $150 \mathrm{TWh}$. Such a change could be viewed as too expensive because of the additional capacity to be built. Actually it is not so, but just the opposite: Spain's current capacity is $25.2 \mathrm{GW}$, and it worked in 2012 just 1500 hours. If this capacity operated 6000 hours more, the additional production would be just 150 TWh. This is another important synergic effect.

The differences between both cases are paramount in energy, $\mathrm{CO}_{2}$ and money. The latter would set up another problem, related to taxes. Taxes on electricity are much smaller, in percentage, than taxes on oil products. Current values are $25 \%$ for the former and $100 \%$ for the latter, over the commercial base price; which means that taxes collection in the oil case would be close to $30 \mathrm{~b} €$. In the gas case, it would be only 3 .

This scenario of EVs indirectly powered by gas deserves much more attention, in order to anticipate hidden costs and technology showstoppers. Of course, such a change would not happen overnight, but in a few decades, taking into account the car replacement rate and other industrial and financial limitations. Very likely, the plugin hybrid car will be an intermediate step in this quest to energy sustainability. Take into account that RES would be a complementary mate for GCC, which already work closely connected in Spain's electricity system.

In summary, a new hierarchy of energy goods and energy applications could appear, and a better integral use of energy will take place. In that highly electrified scenario, where a high fraction of the supply will come from Renewables, macro regulation will be essential, which would need very reliable and flexible energy storage with very rapid reaction. This mission could be satisfied by petroleum products, as kerosene or gasoline, burned in fluid-fired turbines with high efficiency and rapid reaction. They are much simpler and cheaper to store than any other alternative that could give similar performances.

\section{Sustainable Energy by Chance? The Driving Force of Technology}

Such an ideal scenario as the one depicted in the previous section would be possible if technology development succeeds in the several important challenges that this pathway conveys. It is worth pointing out that previous estimates are within the limits of the laws of Physics, as Carnot's theorem or Hess' law on formation heat. The actually pending problem is to find suitable materials for the mechanisms and transformations embodied in the new Energy Industry. In this context, it must be cited [82] the EU Commission's Staff Working Paper, "Materials Roadmap Enabling Low Carbon Energy Technologies", SEC 1609, where a matrix type analysis is presented, as can be seen in Figure 7.

As the study is oriented to Energy generation Technologies, batteries are only considered within the umbrella of "Energy storage", but not as a critical part of EV. In fact, this name never appears, although some of the data contained in the chapter of energy storage are useful to assess the potential and drawbacks of lithium batteries, which are generally considered the best adapted to EV requirements.

One of the key problems is the weight. At present, the maximum specific energy contained in a Li-ion battery is close to $0.25 \mathrm{kWh} / \mathrm{kg}$, but the value considered as safe

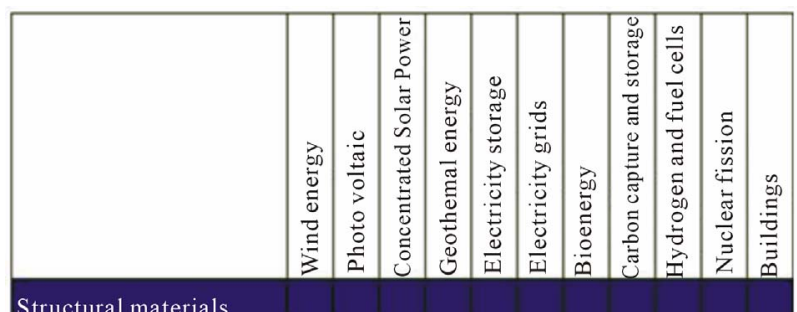

\section{Structural materials}

\begin{tabular}{|c|c|c|c|c|c|c|c|c|c|c|}
\hline Fibre reinforced materials & $\mathrm{x}$ & $\mathrm{X}$ & & & $\mathrm{x}$ & & & $\mathrm{X}$ & $\mathrm{x}$ & \\
\hline $\begin{array}{l}\text { High temperature, low } \\
\text { temperature and } \\
\text { corrosionresistant } \\
\text { materials }\end{array}$ & $\mathrm{x}$ & $\mathrm{x}$ & $\mathrm{X}$ & $\mathrm{X}$ & & $\mathrm{X}$ & $\mathrm{X}$ & $\mathrm{X}$ & $\mathrm{x}$ & \\
\hline $\begin{array}{l}\text { Strutural steel components } \\
\text { and related joining } \\
\text { techniques }\end{array}$ & $\mathrm{x}$ & $\mathrm{x}$ & $\mathrm{x}$ & $\mathrm{x}$ & & $\mathrm{X}$ & $\mathrm{x}$ & & $\mathrm{x}$ & $\mathrm{x}$ \\
\hline Advanced concretes & $\mathrm{x}$ & & $\mathrm{X}$ & & & $\mathrm{X}$ & & & $\mathrm{X}$ & $\mathrm{x}$ \\
\hline Functional materials & & & & & & & & & & \\
\hline
\end{tabular}

\begin{tabular}{|c|c|c|c|c|c|c|c|c|c|c|c|}
\hline Separation membranes & & & & $\mathrm{x}$ & & & $\mathrm{x}$ & $\mathrm{x}$ & $\mathrm{x}$ & & $\mathrm{x}$ \\
\hline Catalyst and electrolytes & & & & & $\mathrm{X}$ & & $\mathrm{x}$ & $\mathrm{x}$ & $\mathrm{x}$ & & \\
\hline $\begin{array}{l}\text { Solid catalyst, sorbents } \\
\text { and } \mathrm{O} 2 \text { carriers }\end{array}$ & & & & & $\mathrm{x}$ & & $\mathrm{x}$ & $\mathrm{x}$ & $\mathrm{x}$ & & \\
\hline $\begin{array}{l}\text { High temperature } \\
\text { superconducting materials }\end{array}$ & $\mathrm{x}$ & & & & & $\mathrm{x}$ & & & & & \\
\hline $\begin{array}{l}\text { High temperature heat } \\
\text { storage materials }\end{array}$ & & & $\mathrm{x}$ & & $\mathrm{x}$ & & & & $\mathrm{x}$ & & \\
\hline $\begin{array}{l}\text { (High temperature) } \\
\text { insulating materials }\end{array}$ & & & $\mathrm{x}$ & $\mathrm{x}$ & & $\mathrm{x}$ & & $\mathrm{x}$ & & $\mathrm{x}$ & $\mathrm{x}$ \\
\hline Materials for power electronics & $\mathrm{X}$ & $\mathrm{x}$ & & $\mathrm{x}$ & & $\mathrm{X}$ & & & & & \\
\hline Heat transfer fluids & & & $\mathrm{x}$ & $\mathrm{x}$ & & & & & & $\mathrm{X}$ & \\
\hline \multicolumn{12}{|l|}{ Manufacturing techniques } \\
\hline Coating and coating techniques & $\mathrm{x}$ & $\mathrm{X}$ & $\mathrm{x}$ & $\mathrm{X}$ & $\mathrm{x}$ & & $\mathrm{x}$ & $\mathrm{X}$ & $\mathrm{X}$ & $\mathrm{X}$ & $\mathrm{x}$ \\
\hline Coating monitoring techniques & $\mathrm{x}$ & $\mathrm{x}$ & & $\mathrm{x}$ & $\mathrm{x}$ & & $\mathrm{x}$ & $\mathrm{x}$ & $\mathrm{x}$ & $\mathrm{x}$ & \\
\hline
\end{tabular}

Figure 7. Research areas common to several technologies [82]. 
enough for public use is $0.14 \mathrm{kWh} / \mathrm{kg}$, which represents 1 $\mathrm{km} / \mathrm{kg}$ of battery in a medium size E. This obviously is a major drawback in this idea, because autonomy of 400 $\mathrm{km}$ would require $400 \mathrm{~kg}$ of batteries, occupying a baggage trunk (but distributed across the car structure. The specific cost is not yet fully commercial, and it ranges now between 500 and $1000 € / \mathrm{kWh}$. Ref. [82] aims at reaching $0.2 \mathrm{kWh} / \mathrm{kg}$ of working value, with a price of $200 € / \mathrm{kWh}$ in the decade $2020-2030$. The battery set for $60 \mathrm{kWh}$ (400 km approximately) would cost 12,000 €, which is indeed a high number. However it is not a consumable, it is an investment. Take also into account that an internal combustion car would use circa 30 liters of gasoline with a price of $45 €$, and the electric car would recharge $0.06 \mathrm{MWh}$, which would be $6 €$ (without taking into account any change in taxes). The fuel cost difference would be close to $0.1 € / \mathrm{km}$, which means that the investment would be recovered in $120,000 \mathrm{~km}$.

Although these numbers are plagued with uncertainties, they are good indicators of the order of magnitude of the problems we will have to address in this quest. For instance, the problem of battery weight seems worse than the problem of money, because embodying 300 to $400 \mathrm{~kg}$ of replaceable batteries into a car is not impossible, but it must be done safely for all conditions and easy to replace. Accounting for the actual value of the newly charged battery and discounting the worth of the given battery could be done by a set of tests made with suitable instruments in the filling stations [68], in such a way that refilling would not be time-consuming.

In summary, technology development has the key for this race, which could set up an Energy scenario much cleaner than any other of the ones studied to combat Global Warming [83] which are based on evolutionary changes in the automobiles, as:

1) Vehicle mass is reduced by $15 \%$ (baseline) and $22 \%$ (advanced) by a combination of greater use of high strength steel, aluminum and plastics coupled with advanced design.

2) Tyre rolling resistance coefficient is reduced from the current 0.009 to 0.008 (baseline) and 0.006 (advanced).

3) Drag coefficient is reduced to 0.27 (baseline) and 0.22 (advanced). The baseline level is at the level of the best current vehicles, while the advanced level should be readily obtainable for the best vehicles in 2020, but seems quite ambitious for a fleet average.

4) Indicated engine efficiency increases to $41 \%$ in both baseline and advanced versions. This level of efficiency would likely require direct injection, full valve control (and possibly camless valves) and advanced engine combustion strategies.

EV offer a totally set of possibilities $[84,85]$ to reshape both the transportation system [86-89] and the Energy system $[89,90]$. It can provide a better overall performance from a comprehensive energy conversion chain [91]. In a society as ours, so dependent on petroleum, the myth of the "oil peak" and the decline in oil production stir some fears [92] but arguments exposed in this paper clearly pointed out that other hydrocarbons, suitably merged with emerging technologies, will open a new macroeconomic cycle with an enormous importance of Energy.

\section{The Role of Corporations}

Deep changes as the one analyzed in this paper do not evolve by themselves in modern societies, because they are too complex and too expensive in the early phases of development. Policy makers must use economic incentives to make these changes a reality. Besides this side of the innovation triangle (funding agencies), other two sides are necessary: research institutions and industrial corporations. Scientific knowledge requires a first step of basic and applied research to be converted into technology elements, and then corporations must use those elements for building a new, and profitable, commercial initiative.

Corporations have the skills and the expertise for converting conceptual advancements into commercial realities, and it has been so in many outstanding examples both in the automobile industry and the energy sector. This sector shows a sort of corporation classification in three levels:

- Energy procurement;

- Energy conversion;

- Energy applications.

Corporations are usually specialized at one level. This fact should be reviewed, because a good merging between markets and technologies needs some continuity between levels. It seems convenient for a corporation to work in levels 1 and 2, or levels 2 and 3. In the first case, some hydrocarbon corporations could find useful to work also in electricity generation, to have a more flexible and independent reaction at tactical level, and more strength in strategic planning. In the second case, electricity generators could be operative in the battery field. Note that the battery inventory in a system will be larger than the inventory needed for powering the cars, and batteries should be managed as electricity storage in general. It goes without saying that Information and Communication Technologies would be an essential tool for the system to be actually smart, so that the system would work in the most efficient state, compatible with satisfying the needs or anticipated consumption an individual customer could declare.

Knowledge acquisition by corporations and steps from knowledge theory to management practice will be a challenge for adapting the company to the new potential 
situation [93-96]. This is one side of the coin. Another side is that corporations need to give credibility to these proposals and potential lines of action. A cool reaction from them would really be a setback for this scenario. Of course, policy makers can use economic incentives for stimulating a line of development, but such a policy should be very limited in budget and time span for the new ideas be credible.

In the first stage of research and innovation, cooperation among companies and research institutions can accelerate knowledge acquisition by corporations, but next stages must be based in competition, which really marks the objective of corporation knowledge. Successful knowledge management [97] will be assessed by results, particularly in relation to get a sizeable share of the new market, which is the objective of the company. It could be said that a mutual benefit is established between the new idea and the corporations involved in their deployment and exploitation. The idea needs the corporation to acquire full credibility, and corporations need the idea to make business.

\section{Conclusions}

The drive of technology advancement and the thrust of the natural gas market in the USA following the commercial explosion of shale gas can be the main starting points of a new phase in the Energy industry. The actual evolution of this field will depend on many factors, including the complex world of international relations and political decisions that do not always follow trade guidelines, and do sometimes depend on other type of interests.

This paper was not intended for forecasting the future of Energy along with the future of our planet. The objective was to study the inherent features of important emerging energy technologies and to analyze the ways of interacting with new evolving markets, in order to find new possibilities for the future of Energy, and to evaluate them under a triple criterion of overall energy efficiency, economic viability and reduction in $\mathrm{CO}_{2}$ emissions.

It is a paradox that the best merging to produce a high quality energy scenario is between the New Gas Market stimulated by shale gas extraction and the EV, which do belong to totally different initiatives. As a matter of fact, production from shale's is a new activity originated in the USA and was totally separated from the initiatives in the automobile industry in the quest to the EV. However, they merge quite well together with the important bridge of GCC as electricity generators. Moreover, RES can also fit well into this scenario, because they are already closely connected to GCC to guarantee meeting the electricity demand, and the EV will be the way to put RES into the car's fuel tank.

The integral energy efficiency of the proposed sce- nario is much higher than the current one. For the ground transportation system, the present overall efficiency is around $25 \%$, while the new case will have at least an overall efficiency of $40 \%$.

The economic impact also shows better results for the new scenario; although investments on EV will require more money than continuation of the existing production of cars with internal combustion engines. Looking at the problem from the viewpoint of customers, EVs will convey an extra-cost for the battery that could be estimated in $12,000 €$ more for the car; which could be compensated by savings in refueling in $120,000 \mathrm{~km}$.

Very likely, the biggest impact would be in $\mathrm{CO}_{2}$ emissions, which could be cut to less than half of the current value, for the same economic activity. Of course, this point presumes that shale gas extraction will be done according to "golden rules" [84] to avoid methane leakage into the atmosphere.

So to speak, shale gas was not in the Energy Agenda of policy makers in the post-Kyoto Protocol era, but it has gained ground in a very short time. It is worth citing the document [98], "Coping with high debt and sluggish growth", included in the WEO 2012 of the International Monetary Fund, (October 2012).

One of the five boxes [98, p.54] devoted to outstanding trends and facts that could have some strength to pull us out of the crisis which is the "Unconventional Energy in the United States". Its analysis does not go up to the level of the prospect presented in this paper, but many points are very similar. In that box it is written "natural gas prices were heavily regulated, with regulators using oil prices as a reference for gas prices. Deregulation and restructuring of the pipeline sector led to a competitive market with direct gas-on-gas competition".

In the prospect presented in this paper, shale gas opens an opportunity for stimulating EV deployment. The new scenario would convey a significant reduction of $\mathrm{CO}_{2}$ emissions, in such a way that all Intergovernmental Panel on Climatic Change scenarios could become obsolete because of the strong reduction caused by higher global efficiency of the system; although a suitable surveillance will be needed to keep methane accidental releases in acceptable values.

The main conclusion is that a phase of cheaper and cleaner energy could appear, although technology and financial challenges, as well as market inertia, can stretch the deployment phase longer with some initial expectations. In this transition, which would likely last thirty years or so, energy corporations will have to face challenges and opportunities to consolidate their working and valueadding status. It could seem as an optimistic dream more than a fact, but shale gas has become a reality before anyone could say it was a dream, and prototypes of EV resemble and the early electric locomotives in a railways 
system then are dominated by steam and diesel engines.

\section{Acknowledgements}

The contents of this paper fully belongs to the Ph.D. Thesis of the author (JMM-VP) who recognizes that former studies at The Colorado School of Mines and The French Institute of Petroleum offers unique opportunities to understand the world of Energy, notably the hydrocarbon sector.

Further, reproduction of relevant figures from the following references is highly recognized:

- The European Union Commission; paper "Materials Roadmap Enabling Low Carbon Energy Technologies", SEC (2011) 1609, [85].

- The International Energy Agency: "Golden rules for a golden age of gas", [84].

- NREL/CP-5500-4930, by C. Turchi et al. [48].

- DOE/GO-102012-3839 (2012) by D.Feldman et al. [44].

\section{REFERENCES}

[1] W. Häfele, "Energy in a Finite World. Paths to a Sustainable Future. Energy in a Finite World. A Global System Analysis," Ballinger Pu. Co., USA, 1981.

[2] G. Brundtland, "Our Common Future," Oxford University Press, USA, 1987.

[3] J. Rifkin, "The Third Industrial Revolution: How Lateral Power Is Transforming Energy, the Economy, and the World," Palgrave Macmillan, UK, 2011.

[4] J. Bloodgood and D. Salisbury, "Understanding the Influence of Organizational Change Strategies on Information Technology and Knowledge Management Strategies," Decision Support Systems, Vol. 31, No. 1, 2001, pp. 5569. http://dx.doi.org/10.1016/S0167-9236(00)00119-6

[5] C. López-Nicolás and A. Meroño-Cerdán, "Strategic Knowledge Management, Innovation and Performance," International Journal of Information Management, Vol. 31, No. 6, 2011, pp. 502-509.

http://dx.doi.org/10.1016/j.ijinfomgt.2011.02.003

[6] M. Shina, R. Holden and R. Schmidt, "From Knowledge Theory to Management Practice: Towards an Integrated Approach," Information Processing \& Management, Vol. 37, No. 2, 2001, pp. 335-355. http://dx.doi.org/10.1016/S0306-4573(00)00031-5

[7] BP Statistical Review of World Energy, 2011. http://www.bp.com/sectionbodycopy.do? categoryId $=750$ $0 \&$ content $I d=7068481$

[8] World Energy Outlook, International Energy Agency, 2009. www.worldenergyoutlook.com

[9] Red Eléctrica de España. http://www.ree.es/sistema_electrico/pdf/infosis/sintesis_R EE_2010.pdf

[10] Eurostats, "Energy, Transport and Environment Indicators," 2010. http://ec.europa.eu/erostats

[11] SEDIGAS Informe Anual, 2011. www.sedigas.es
[12] OMEL, 2012.

http://www.omie.es/files/flash/ResultadosMercado.swf

[13] Comision Nacional de la Energia, 2012. www.cne.es

[14] Carbon Sequestration Leadership Forum website, 2011. www.cslf.org

[15] International Partnership on the Hydrogen Economy, 2012. http://www.iphe.net/

[16] Generation 4 Forum Website, 2011. www.gen-4.org

[17] H. Terrell, "US Gas Reserves Estimated at Record High," World Oil, Vol. 232, No. 5, 2011, p. 13.

[18] K. Costello, “Going 'Long' with Natural Gas," The Electricity Journal, Vol. 24, No. 5, 2011, pp. 42-49. http://dx.doi.org/10.1016/j.tej.2011.05.005

[19] T. C. Kinnaman, "The Economic Impact of Shale Gas Extraction: A Review of Existing Studies," Ecological Economics, Vol. 70, 2011, pp. 1243-1249. http://dx.doi.org/10.1016/j.ecolecon.2011.02.005

[20] R. Mcllvaine and A. James, "The Potential of Shale Gas," World Pumps, Vol. 7, 2010, pp. 16-18. http://dx.doi.org/10.1016/S0262-1762(10)70195-4

[21] D. Rahm, "Regulating Hydraulic Fracturing in Shale Gas Plays: The Case of Texas," Energy Policy, Vol. 39, 2011, pp. 2974-2981. http://dx.doi.org/10.1016/j.enpol.2011.03.009

[22] P. Kulkarni, "Shale Search Goes Global," World Oil, Vol. 231, No. 12, 2010, pp. D73-D78.

[23] R. W. Howarth, R. Santoro and A. Ingraffea, "Methane and the Greenhouse-Gas Footprint of Natural Gas from Shale Formations," Climatic Change, Vol. 106, No. 4, pp. 679-690. http://dx.doi.org/10.1007/s10584-011-0061-5

[24] J. D. Arthur, H. W. Hochheiser and B. J. Coughlin, "State and Federal Regulation of Hydraulic Fracturing: A Comparative Analysis," Society of Petroleum Engineers-SPE Hydraulic Fracturing Technology Conference, 2011, pp. 522-529.

[25] C. E. Bell and H. D. Brannon, "Redesigning Fracturing Fluids for Improving Reliability and Well Performance in Horizontal Tight Gas Shale Applications," Society of Petroleum Engineers-SPE Hydraulic Fracturing Technology Conference, 2011, pp. 181-189.

[26] R. F. Lafollette and W. D. Holcomb, "Practical Data Mining: Lessons Learned from the Barnett Shale of North Texas," Society of Petroleum Engineers-SPE Hydraulic Fracturing Technology Conference, 2011.

[27] P. Paquet, T. Bews, E. Viala and M. Pearson, "Overview of the Emerging Unconventional Oil and Gas Regulatory Framework in Quebec Vis-a Vis Its Western Canadian Counterparts," Society of Petroleum Engineers-Canadian Unconventional Resources and International Petroleum Conference, 2010, pp. 2414-2434.

[28] Editorial News, "Quebec's Shale-Gas Moratorium," Petroleum Economist, Vol. 78, No. 3, 2011.

[29] I. M. Mohamed, R. A. Nasralla, M. A. Sayed, M. Marongiu-Porcu and C. A. Ehligh-Economides, "Evaluation of After-Closure Analysis Technique for Tight and Shale Gas Formations," Society of Petroleum Engineers-SPE Hydraulic Fracturing Technology Conference, 2011, pp. 
227-238.

[30] B. Sorensen, "Renewable Energies," 2nd Edition, Academic Press, Inc., 2002.

[31] Human Development Index (HDI). http://hdr.undp.org/en/statistics/hdi/\#top

[32] P. del Río and G. Unruh, "Overcoming the Lock-Out of Renewable Energy Technologies in Spain: The Cases of Wind and Solar Electricity," Renewable and Sustainable Energy Reviews, Vol. 11, No. 7, 2007, pp. 1498-1513. http://dx.doi.org/10.1016/j.rser.2005.12.003

[33] G. Martínez Montes, E. Prados Martín and J. Ordóñez García, "The Current Situation of Wind Energy in Spain," Renewable and Sustainable Energy Reviews, Vol. 11, No. 3, 2007, pp. 467-481. http://dx.doi.org/10.1016/j.rser.2005.03.002

[34] Y. Perez and F. J. Ramos-Real, "The Public Promotion of Wind Energy in Spain from the Transaction Costs Perspective 1986-2007," Renewable and Sustainable Energy Reviews, Vol. 13, No. 5, 2009, pp. 1058-1066. http://dx.doi.org/10.1016/j.rser.2008.03.010

[35] G. Martínez Montes, M. M. Serrano López, M. C. Rubio Gámez and A. Menéndez Ondina, "An Overview of Renewable Energy in Spain. The Small Hydro-Power Case," Renewable and Sustainable Energy Reviews, Vol. 9, No. 5, 2005, pp 521-534.

http://dx.doi.org/10.1016/j.rser.2004.05.008

[36] F. Hernández, M. A. Gual, P. Del Río and A. Caparrós, "Energy Sustainability and Global Warming in Spain," Energy Policy, Vol. 32, No. 3, 2004, pp. 383-394. http://dx.doi.org/10.1016/S0301-4215(02)00308-7

[37] F. Foidart, J. Oliver-Solá, C. M. Gasol, X. Gabarrell and J. Rieradevall, "How Important Are Current Energy Mix Choices on Future Sustainability? Case Study: Belgium and Spain-Projections towards 2020-2030," Energy Policy, Vol. 38, No. 9, 2010, pp. 5028-5037. http://dx.doi.org/10.1016/j.enpol.2010.04.028

[38] C. Batlle and P. Rodilla, "A Critical Assessment of the Different Approaches Aimed to Secure Electricity Generation Supply," Energy Policy, Vol. 38, No. 2010, pp. 71697179. http://dx.doi.org/10.1016/j.enpol.2010.07.039

[39] F. Moreno and J. M. Martinez-Val, "Collateral Effects of Renewable Energies Deployment in Spain: Impact on Thermal Power Plants Performance and Management," Energy Policy, Vol. 39, No. 10, 2011, pp. 6561-6574.

[40] M. Beccali, M. Cellura and M. Mistretta, "Decision-Making in Energy Planning. Application of the Electre Method at Regional Level for the Diffusion of Renewable Energy Technology," Renewable Energy, Vol. 28, No. 13, 2003, pp. 2063-2087. http://dx.doi.org/10.1016/S0960-1481(03)00102-2

[41] J. R. San Cristobal, "Multi-Criteria Decision-Making in the Selection of a Renewable Energy Project in Spain: The Vikor Method," Renewable Energy, Vol. 36, No. 2, 2011, pp. 498-502. http://dx.doi.org/10.1016/j.renene.2010.07.031

[42] K. Cowan and T. Daim, "Comparative Technological RoadMapping for Renewable Energy," Technology in Society, Vol. 31, No. 4, 2009, pp. 333-341. http://dx.doi.org/10.1016/j.techsoc.2009.10.003

[43] APPA, "Estudio del Impacto Macroeconómico de las Energías Renovables en España," 2011. www.appa.es

[44] D. Feldman, G. Barbose, R. Margolis, R. Wiser, N. Darghouth and A. Goodrich, "Photovoltaic Pricing Trends: Historical, Recent and Near-Term Projections," SunShot Initiative, 2012.

[45] J. Muñoz, J. M. Martinez-Val, R. Abbas and A. Abanades, "Dry Cooling with Night Cool Storage to Enhance Solar Power Plant Performance in Extreme Condition Areas," Applied Energy, Vol. 92, 2012, pp. 429-436. http://dx.doi.org/10.1016/j.apenergy.2011.11.030

[46] S. Hasnain, "Review on Sustainable Thermal Energy Storage Technologies. Part I: Heat Storage Materials and Techniques," Energy Conversion \& Management, Vol. 39, No. 11, 1998, pp. 1127-1138. http://dx.doi.org/10.1016/S0196-8904(98)00025-9

[47] A. Gil, M. Medrano, I. Martorell, A. Lázaro, P. Dolado, B. Zalba and L. F. Cabeza, "State of the Art on High Temperature Thermal Energy Storage for Power Generation. Part 1 - Concepts, Materials and Modellization," Renewable and Sustainable Energy Reviews, Vol. 14, No. 1, 2010, pp. 31-55. http://dx.doi.org/10.1016/j.rser.2009.07.035

[48] C. Turchi, M. Mehos, C. K. Ho and G. J. Kolb, "Current and Future Costs for Parabolic Trough Collector and Power Tower Systems in the US Market," NREL/CP-5500-4930, National Renewable Energies Laboratory, USA, 2010.

[49] "Annual Energy Outlook 2011, with Projections to 2035," 2011. www.eia.gov

[50] R. Williams, "Roles for Biomass Energy in Sustainable Development," Industrial Ecology and Global Change, Cambridge University Press, Cambridge, 1994, pp. 199228.

[51] "Biofuels for Transport: Global Potential and Implications for Energy and Agriculture," In: L. Matzny, Ed., Worldwatch Institute, Earthscan Ltd., 2007.

[52] W. Liao, R. Heijungs and G. Huppes, "Is Bioethanol a Sustainable Energy Source? An Energy-, Exergy-, and Emergy-Based Thermodynamic System Analysis," Renewable Energy, Vol. 36, No. 12, 2011, pp. 3479-3487. http://dx.doi.org/10.1016/j.renene.2011.05.030

[53] L. Luo, E. Van Der Voet and G. Huppes, "Life Cycle Assessment and Life Cycle Costing of Bioethanol from Sugarcane in Brazil," Renewable and Sustainable Energy Reviews, Vol. 13, No. 6-7, 2009, pp. 1613-1619. http://dx.doi.org/10.1016/j.rser.2008.09.024

[54] E. Hanff, M.-H. Dabat and J. Blin, "Are Biofuels an Efficient Technology for Generating Sustainable Development in Oil-Dependent African Nations? A Macroeconomic Assessment of the Opportunities and Impacts in Burkina Faso," Renewable and Sustainable Energy Reviews, Vol. 15, No. 5, 2011, pp. 2199-2209. http://dx.doi.org/10.1016/j.rser.2011.01.014

[55] R. Melamu and H. Von Blottnitz, "2nd Generation Biofuels a Sure Bet? A Life Cycle Assessment of How Things Could Go Wrong," Journal of Cleaner Production, Vol. 19, No. 2-3, 2010, pp. 138-144. 
http://dx.doi.org/10.1016/j.jclepro.2010.08.021

[56] Commission Staff Working Document, "Guidelines for Financial Incentives for Clean and Energy Efficient Vehicles," SWD 27 Final, European Union, 2013.

[57] M. Mullen, "The State of Shale Plays in Europe," World Oil, Vol. 231, No. 12, 2010, p. D-79.

[58] Hydrocarbon Processing, "Natural Gas Enters a New Era of Abundance," Hydrocarbon Processing, Vol. 90, No. 4, 2011.

[59] OPEC Bulletin, "Newline: Algeria Said to Be Sitting on Vast Amounts of Shalegas," OPEC Bulletin, Vol. 42, No. 3, 2011, pp. 30-31.

[60] Petroleum Economist, "Natural Gas: GTL: A Glut-Inspired Idea for North America's Shale-Gas Abundance," Petroleum Economist, Vol. 78, No. 1, 2011.

[61] B. Buffet and D. Archer, "Global Inventory of Methane Clathrate: Sensitivity to Changes in the Deep Ocean," Earth and Planetary Science Letters, Vol. 227, No. 3-4, 2004, pp. 185-199.

http://dx.doi.org/10.1016/j.epsl.2004.09.005

[62] A. Demirbas, "Methane Hydrates as Potential Energy Resource: Part 1-Importance, Resource and Recovery Facilities," Energy Conversion and Management, Vol. 51, No. 7, 2010, pp. 1547-1561. http://dx.doi.org/10.1016/j.enconman.2010.02.013

[63] A. Demirbas, "Methane Hydrates as Potential Energy Resource: Part 2-Methane Production Processes from Gas Hydrates," Energy Conversion and Management, Vol. 51, No. 7, 2010, pp. 1562-1571. http://dx.doi.org/10.1016/j.enconman.2010.02.014

[64] K. A. Kvenvolden, "Methane Hydrate-A Major Reservoir of Carbon in the Shallow Geosphere?" Chemical Geology, Vol. 71, No. 1-3, 1988, pp. 41-51.

[65] S. Lee and G. D. Holder, "Methane Hydrates Potential as a Future Energy Source," Fuel Processing Technology, Vol. 71, No. 1-3, 2001, pp. 181-186. http://dx.doi.org/10.1016/S0378-3820(01)00145-X

[66] J. Li, Y. Sheng, J. Wu, J. Chen and X. Zhang, "Probability Distribution of Permafrost along a Transportation Corridor in the Northeastern Quinghai Province of China," Cold Region Science and Technology, Vol. 59, No. 1, 2009, pp. 12-18.

[67] X. Lang, S. Fan and Y. Wang, "Intensification of Methane and Hydrogen Storage in Clathrate Hydrate and Future Prospect," Journal of Natural Gas Chemistry, Vol. 19, No. 3, 2010, pp. 203-209.

http://dx.doi.org/10.1016/S1003-9953(09)60079-7

[68] J. M. Martinez-Val Piera, A. Maldonado and R. R. PonsEsparver, "Adapting Business of Energy Corporations to Macro-Policies Aiming at a Sustainable Development. The Case of New Powering of Automobiles," Energy and Power Engineering, Vol. 5, 2013, pp. 92-108. http://dx.doi.org/10.4236/epe.2013.51010

[69] J. Fernandez, "Energia de la Biomasa," La Energia en Sus Claves, Fundacion Iberdrola, Madrid, 2004.

[70] “Energia 2012," Foro Nuclear, Madrid, 2012. www.foronuclear.org

[71] G. Gutmann, "Hybrid Electric Vehicles and Electrochemical
Storage Systems - A Technology Push-Pull Couple," Journal of Power Sources, Vol. 84, No. 2, 1999, pp. 275-279. http://dx.doi.org/10.1016/S0378-7753(99)00328-6

[72] C. E. Thomas, "Fuel Cell and Battery Electric Vehicles Compared, International," International Journal of Hydrogen Energy, Vol. 34, No. 15, 2009, pp. 6005-6020. http://dx.doi.org/10.1016/j.ijhydene.2009.06.003

[73] G. J. Offer, M. Contestabile, D. A. Howey, R. Clague and N. P. Brandon, "Techno-Economic and Behavioural Analysis of Battery Electric, Hydrogen Fuel Cell and Hybrid Vehicles in a Future Sustainable Road Transport System in the UK," Energy Policy, Vol. 39, No. 4, 2011, pp. 19391950. http://dx.doi.org/10.1016/j.enpol.2011.01.006

[74] T. Kojimaa, T. Ishizua, T. Horibaa and M. Yoshikawa, "Development of Lithium-Ion Battery for Fuel Cell Hybrid Electric Vehicle Application," Journal of Power Sources, Vol. 189, No. 1, 2009, pp. 859-863. http://dx.doi.org/10.1016/j.jpowsour.2008.10.082

[75] P. Moriarty and D. Honnery, "The Prospects for Global Green Car Mobility," Journal of Cleaner Production, Vol. 16, No. 16, 2008, pp. 1717-1726. http://dx.doi.org/10.1016/j.jclepro.2007.10.025

[76] J. Van Mierlo, G. Maggetto and P. Lataire, "Which Energy Source for Road Transport in the Future? A Comparison of Battery, Hybrid and Fuel Cell Vehicles," Energy Conversion and Management, Vol. 47, No. 17, 2006, pp. $2748-2760$.

http://dx.doi.org/10.1016/j.enconman.2006.02.004

[77] K. Ç. Bayindir, M. A. Gözüküçük and A. Teke, "A Comprehensive Overview of Hybrid Electric Vehicle: Powertrain Configurations, Powertrain Control Techniques and Electronic Control Units," Energy Conversion and Management, Vol. 52, No. 2, 2011, pp. 1305-1313. http://dx.doi.org/10.1016/j.enconman.2010.09.028

[78] T. H. Bradley and A. A. Frank, "Design, Demonstrations and Sustainability Impact Assessments for Plug-In Hybrid Electric Vehicles," Renewable and Sustainable Energy Reviews, Vol. 13, No. 1, 2009, pp. 115-128. http://dx.doi.org/10.1016/j.rser.2007.05.003

[79] S. Amjad, S. Neelakrishnan and R. Rudramoorthy, "Review of Design Considerations and Technological Challenges for Successful Development and Deployment of Plug-in Hybrid Electric Vehicles," Renewable and Sustainable Energy Reviews, Vol. 14, No. 3, 2010, pp. 11041110. http://dx.doi.org/10.1016/j.rser.2009.11.001

[80] D. Katsaprakakis, "Introduction of a Wind Powered Pumped Storage System in the Isolated Insular Power System of Karpathos-Kasos," Applied Energy, Vol. 97, 2012, pp. 3848. http://dx.doi.org/10.1016/j.apenergy.2011.11.069

[81] International Energy Agency, "Golden Rules for a Golden Age of Gas," 2012. www.worldenergyoutlook.org

[82] Commission Staff Working Paper, "Materials Roadmap Enabling Low Carbon Energy Technologies," European Union, 2011.

[83] Intergovernmental Panel on Climatic Change, 2013. http://www.ipcc.ch/publications_and_data/ar4/wg3/en/ch 5s5-4-2-1.html

[84] S. Brown, D. Pyke and P. Steenhof, "Electric Vehicles: The 
Role and Importance of Standards in an Emerging Market," Energy Policy, Vol. 38, No. 7, 2010, pp. 3797-3806. http://dx.doi.org/10.1016/j.enpol.2010.02.059

[85] A. K. Srivastava, B. Annabathina and S. Kamalasadan, "The Challenges and Policy Options for Integrating PlugIn Hybrid Electric Vehicle into the Electric Grid," The Electricity Journal, Vol. 23, No. 3, 2010, pp. 83-91.

[86] H. B. Dulal, G. Brodnig and C. G. Onoriose, "Climate Change Mitigation in the Transport Sector through Urban Planning: A Review," Habitat International, Vol. 35, No. 3, 2011, pp. 494-500. http://dx.doi.org/10.1016/j.habitatint.2011.02.001

[87] T. Mattila and R. Antikainen, "Backcasting Sustainable Freight Transport Systems for Europe in 2050," Energy Policy, Vol. 39, No. 3, 2011, pp. 1241-1248. http://dx.doi.org/10.1016/j.enpol.2010.11.051

[88] P. Moriarty and D. Honnery, "Low-Mobility: The Future of Transport," Futures, Vol. 40, No. 10, 2008, pp. 865872. http://dx.doi.org/10.1016/j.futures.2008.07.021

[89] G. Klaassen and K. Riahi, "Internalizing Externalities of Electricity Generation: An Analysis with Message-Macro," Energy Policy, Vol. 35, No. 2, 2007, pp. 815-827. http://dx.doi.org/10.1016/j.enpol.2006.03.007

[90] E. Lebre, J. Borghetti, L. Basto and T. Lauria, "Sustainable Expansion of Electricity Sector: Sustainability Indicators as an Instrument to Support Decision Making," Renewable and Sustainable Energy Reviews, Vol. 14, No. 1, 2010, pp. 422-429. http://dx.doi.org/10.1016/j.rser.2009.07.033

[91] E. Heiskanen, "The Institutional Logic of Life Cycle Thinking," Journal of Cleaner Production, Vol. 10, No. 5, 2002, pp. $427-437$.

http://dx.doi.org/10.1016/S0959-6526(02)00014-8

[92] P. Roberts, "The Last Drops: How to Bridge the Gap between Oil and Green Energy," Popular Science, 2011.

[93] M. Liu and N. Liu, "Sources of Knowledge Acquisition and Patterns of Knowledge-Sharing Behaviors. An Empirical Study of Taiwanese High-Tech Firms," International Journal of Information Management, Vol. 28, No. 5, 2008, pp. 423-432. http://dx.doi.org/10.1016/j.ijinfomgt.2008.01.005

[94] C. V. Holsapple and M. Singh, "The Knowledge Chain Model: Activities for Competitiveness," Expert Systems with Applications, Vol. 20, No. 1, 2001, pp. 77-98. http://dx.doi.org/10.1016/S0957-4174(00)00050-6

[95] C. Kai, "Performance Evaluation of Enterprise Knowledge Management," Procedia Engineering, Vol. 23, 2011, pp. 733-739. http://dx.doi.org/10.1016/j.proeng.2011.11.2573

[96] M. Shina, T. Holden and R. Schmidt, "From Knowledge Theory to Management Practice: Towards an Integrated Approach," Information Processing \& Management, Vol. 37, No. 2, 2001, pp. 335-355. http://dx.doi.org/10.1016/S0306-4573(00)00031-5

[97] T. Changa and T. Wang, "Using the Fuzzy Multi-Criteria Decision Making Approach for Measuring the Possibility of Successful Knowledge Management," Information Sciences, Vol. 179, No. 4, 2009, pp. 355-370. http://dx.doi.org/10.1016/j.ins.2008.10.012

[98] World Economic Outlook 2012, "Coping with High Debt and Sluggish Growth,” International Monetary Fund, 2012.

IEA: International Energy Agency

LHV: Low Heating Value

PV: Photovoltaic

RE: Renewable Energies

RES: Renewable Energy Sources

TES: Thermal Energy Storage

Toe: Ton of Oil Equivalent

WEO: World Energy Outlook 